\title{
ANALISIS EFISIENSI PRODUKSI USAHATANI PADI LADANG DI KECAMATAN SIDOMULYO KABUPATEN LAMPUNG SELATAN
}

\author{
(Analysis of Production Efficiency of Upland Rice Farming in Sidomulyo Sub District Of \\ South Lampung Regency)
}

Suci Rodian Noer, Wan Abbas Zakaria, Ktut Murniati

Jurusan Agribisnis, Fakultas Pertanian, Universitas Lampung, J1. Prof. Dr. Soemantri Brojonegoro No. 1

Bandar Lampung 35145, Telp. 081278309980,e-mail : sucirodiyan21@ gmail.com

\begin{abstract}
The research aims to know the income level and production's efficiency of upland rice farming in Sidomulyo Subdistrict of South Lampung Regency. The Location of this research was chosen purposively with consideration that the area is upland rice production centers in Lampung. This research used a survey method and the data were collected in Nov-Dec 2016. The samples consist of 54 upland rice farmers selected using stratified random sampling method. The income level of upland rice farming is analyzed by using income analysis method. The production efficiency of upland rice farming is analyzed by using production stochastic frontier function analysis method. The results showed that the income level of upland rice farming in rainy season (November 2016 until March 2017) was provitable about Rp 1.381.414/ha, R/C value of total cost was about 1.22. The production efficiency level of upland rice farming was 89 percent (not efficienct yet).
\end{abstract}

Key words : efficiency, income, production, upland rice

\section{PENDAHULUAN}

Memposisikan sektor pertanian dalam pembangunan nasional merupakan kunci utama keberhasilan dalam mewujudkan Indonesia yang bermartabat, mandiri, maju, adil dan makmur. Pembangunan pertanian ke depan untuk mewujudkan kedaulatan pangan, agar Indonesia sebagai bangsa dapat mengatur dan memenuhi kebutuhan pangan rakyatnya secara berdaulat (Kementan 2015).

Kekhawatiran akan ketidakcukupan ketersediaan beras dalam memenuhi kebutuhan masyarakat di Indonesia bukan tanpa alasan. Alih fungsi lahan pertanian di Indonesia semakin meningkat setiap tahunnya. Luas lahan yang terkonversi tidak mampu diimbangi dengan ekstensifikasi melalui pembukaan sawah baru. Lahan produktif untuk pangan kian defisit. Setiap tahun tak kurang dari 110.000 ha sawah beralih fungsi. Permasalahan peningkatan konversi lahan sawah diatasi dengan peningkatan produktivitas dan pengelolaan lahan kering yang masih cukup luas (Kementan 2015).

Sejalan dengan meningkatnya jumlah penduduk dan pendapatan penduduk kebutuhan beras akan terus meningkat. Untuk mengantisipasi peningkatan kebutuhan beras tersebut maka produksi padi harus ditingkatkan dengan laju yang tinggi agar kebutuhan beras nasional dapat dipenuhi. Lahan kering di Indonesia merupakan modal besar yang dapat mendukung dalam pengembangan dan peningkatan produksi pangan. Pengelolaan lahan kering perlu dilakukan untuk memperkuat pemenuhan pangan penduduk dan pemantapan ketahanan pangan.

Kabupaten Lampung Selatan merupakan salah satu sentra produksi padi ladang di Provinsi Lampung dengan hasil produktivitas 32,94 ku/ha (BPS 2016). Padi ladang merupakan tanaman padi yang ditanam baik pada lahan kering yang datar maupun lahan kering berlereng tanpa galengan dimana pengolahan lahan dan tanam pada kondisi kering serta pertumbuhan dan produksinya sangat tergantung pada ketersediaan curah hujan yang mempengaruhi kelembaban tanah (BPTP NAD 2009).

Kecamatan Sidomulyo merupakan kecamatan penghasil padi ladang, dengan luas panen (790 ha) dan produktivitas $(30,11 \mathrm{ku} / \mathrm{ha})$ tertinggi ke tiga di Kabupaten Lampung Selatan (BPS 2016). Kecamatan Sidomulyo adalah kecamatan dengan jumlah petani padi ladang tertinggi. Menurut Permadi dan Toha (1996), sebagian besar petani menanam padi ladang dengan penggunaan varietas unggul, teknik budi daya optimal, dan pengendalian hama dan penyakit secara baik, 
produktivitas padi ladang dapat mencapai 54,00$68,00 \mathrm{ku} / \mathrm{ha}$. Namun, produktivitas tanaman padi ladang di Kecamatan Sidomulyo pada tahun 2015 hanya mencapai $30,10 \mathrm{ku} / \mathrm{ha}$ per tahun, produktivitas rendah salah satu indikator usahatani belum efisien. Berdasarkan permasalahan tersebut maka penelitian ini bertujuan mengetahui tingkat pendapatan usahatani padi ladang, dan efisiensi produksi usahatani padi ladang di Kecamatan Sidomulyo Kabupaten Lampung Selatan.

\section{METODOLOGI PENELITIAN}

Penelitian ini menggunakan metode survei. Penelitian ini dilakukan di Kecamatan Sidomulyo, Kabupaten Lampung Selatan dengan pertimbangan bahwa Kecamatan Sidomulyo adalah kecamatan sentra penghasil padi ladang. Kecamatan tersebut dipilih dua desa yaitu, Desa Bandar Dalam dan Desa Campang Tiga dengan pertimbangan desa tersebut memiliki lahan padi ladang terluas. Sampel diambil secara stratified random sampling sebanyak 54 petani.

Data yang digunakan adalah data primer dan data sekunder. Data primer diperoleh dengan wawancara langsung terhadap responden rumah tangga petani. Data sekunder diperoleh dari dinas atau instansi terkait yang berhubungan dengan penelitian. Pengambilan data dilaksanakan bulan Oktober 2016 sampai Desember 2016.

Metode analisis data yang digunakan adalah analisis deskriptif dan analisis kuantitatif. Analisis kuantitatif digunakan untuk menghitung hasil produksi, harga hasil produksi, jumlah faktor produksi dan harga faktor produksi dan tingkat pendapatan. Analisis tujuan pertama menggunakan analisis pendapatan usahatani dan analisis tujuan kedua menggunakan analisis fungsi produksi stochastic frontier.

Analisis pendapatan digunakan untuk mengetahui tingkat pendapatan petani padi ladang. Menurut Soekartawi (1995) pendapatan usahatani padi ladang menggunakan rumus berikut.

$\pi=\mathrm{TR}-\mathrm{TC}$ atau $\pi=\mathrm{Py} . \mathrm{Y}-(\mathrm{FC}+\mathrm{VC}) . .(1)$

Keterangan:

$\Pi \quad=$ Pendapatan/keuntungan $(\mathrm{Rp})$

$\mathrm{TR}=$ Penerimaan $(\mathrm{Rp})$

TC = Biaya total $(\mathrm{Rp})$

Py $\quad=$ Harga produksi $(\mathrm{Rp} / \mathrm{Kg})$

$\mathrm{Y}=$ Jumlah produksi $(\mathrm{Kg})$

$\mathrm{FC} \quad=$ Biaya tetap $(\mathrm{Rp})$
$\mathrm{VC} \quad=$ Biaya variabel $(\mathrm{Rp})$.

Menurut Soekartawi (1984) untuk mengetahui usahatani menguntungkan atau tidak, maka dianalisis dengan $\mathrm{R} / \mathrm{C}$ ratio yaitu perbandingan penerimaan total yang diperoleh dengan biaya total yang dikeluarkan. Dengan rumus sebagai berikut.

$\mathrm{R} / \mathrm{C}=\mathrm{TR} / \mathrm{TC}$

Kriteria dalam perhitungan pendapatan, yaitu.

1) Jika $R / C>1$, maka usahatani menguntungkan

2) Jika $R / C=1$, maka usahatani tidak untung dan tidak rugi, dan

3) Jika $\mathrm{R} / \mathrm{C}<1$, maka usahatani rugi

Analisis efisiensi produksi digunakan untuk menentukan usahatani yang dilakukan efisien atau tidak efisien. Penelitian ini mengukur efisiensi ekonomi, efisiensi teknis dan harga (alokatif). Keadaan dikatakan efisiensi ekonomi jika usaha pertanian tersebut mencapai efisiensi teknis dan efisiensi harga. Asumsi yang digunakan adalah bentuk fungsi produksi stochastic frountier. Secara matematis model persamaan penduga fungsi produksi stochastic frontier pada usahatani padi ladang dalam penelitian ini dapat ditulis sebagai berikut (Coelli dan Battese 1998).

$$
\begin{aligned}
& \ln Y=\beta_{0}+\beta_{1} \ln X_{1}+\beta_{2} \ln X_{2}+\beta_{3} \ln X_{3}+\beta_{4} \ln X_{4}+v i \\
& -\mathrm{u}
\end{aligned}
$$

Keterangan :

$\begin{array}{lll}\mathrm{Y} & & \text { Produksi padi ladang }(\mathrm{kg} \text { GKG}) \\ \mathrm{X} 1 & & =\text { Luas lahan }(\mathrm{ha}) \\ \mathrm{X} 2 & & \text { Benih }(\mathrm{kg}) \\ \mathrm{X} 3 & & =\text { Pupuk TSP }(\mathrm{kg}) \\ \mathrm{X} 4 & & \text { Tenaga kerja }(\mathrm{HOK}) \\ \beta 0 & & \text { Intersep } \\ \beta 1, \beta 2, \beta 3, \beta 4 & =\text { Parameter yang diestimasi } \\ \text { vi- ui } & & =\text { Error term }\end{array}$

Efisiensi teknis masing-masing petani dihitung dengan menggunakan rumus berikut (Coelli dan Battese 1998):

$\mathrm{TE}=\mathrm{y}_{\mathrm{i}} / \mathrm{y}^{*}$

Keterangan :

$\mathrm{yi}=$ Produksi aktual dari pengamatan

$\mathrm{y}^{*}=$ Dugaan produksi frontier yang diperoleh dari produksi stochastic frontier.

Metode inefisiensi teknis yang digunakan dalam penelitian ini mengacu pada model efek inefisiensi 
teknis yang dikembangkan oleh Coelli dan Battese (1998).

$\mathrm{Ui}=\alpha_{0}+\alpha_{1} Z_{1}+\alpha_{2} Z_{2}+\alpha_{3} Z_{3}+\alpha_{4} Z_{4}$

Keterangan :

$\mathrm{Ui}=$ Efek inefisiensi teknik

$\alpha_{0}=$ Konstanta

$\mathrm{Z}_{1}=$ Umur petani (tahun)

$Z_{2}=$ Tingkat pendidikan formal petani (tahun)

$\mathrm{Z}_{3}=$ Pengalaman berusahatani (tahun)

$\mathrm{Z}_{4}=$ Dummy sumber modal (modal sendiri=1 dan modal pinjaman $=0$ )

Tingkat efisiensi ekonomi secara keseluruhan ditentukan dengan rasio total biaya produksi minimum $(\mathrm{Ci})$ dengan total biaya produksi aktual atau biaya total produksi $\left(\mathrm{Ci}^{*}\right)$, sehingga persamaan menjadi :

$\mathrm{EE}=\mathrm{C}_{\mathrm{i}} / \mathrm{C}_{\mathrm{i}}{ }^{*}$

Keterangan :

$\mathrm{Ci}=$ Rasio total biaya produksi minimum

$\mathrm{Ci}^{*}=$ Total biaya produksi aktual

Rumus efisiensi alokatif (AE) per individu usahatani adalah sebagai berikut:

$\mathrm{AE}=\mathrm{EE} / \mathrm{ET}$

Keterangan :

$\mathrm{EE}=$ Efisiensi ekonomi

$\mathrm{ET}=$ Efisiensi teknis

\section{HASIL DAN PEMBAHASAN}

\section{Karakteristik Responden Petani Padi Ladang}

Rata-rata umur petani padi ladang 41 tahun. Hal ini berarti kelompok umur tersebut berada pada usia produktif (Mantra 2008). Petani padi ladang sebagian besar (56 persen) merupakan lulusan Sekolah Dasar (SD). Pengalaman berusahatani dapat memberikan dampak terhadap cara pengolahan usahatani dan tingkat keberhasilannya. Semakin lama pengalaman usahatani maka petani akan memiliki keterampilan dan pengetahuan yang lebih luas mengenai usahatani. Petani padi ladang sebesar 42 persen telah berusahatani padi ladang selama 9-12 tahun. Lahan merupakan faktor pendukung usahatani, semakin luas lahan yang diusahakannya maka diharapkan meningkatnya produksi yang diperoleh. Penguasaan lahan petani responden berkisar antara 0,25-1,5 hektar dengan rata-rata penguasaan lahan seluas 0,59 hektar.
Benih merupakan sarana poduksi utama dalam kegiatan usahatani. Besarnya produksi padi ladang yang dihasilkan dalam usahatani tergantung pada penggunaan benih. Varietas padi yang digunakan ada tiga, yaitu padi muncul, Ciherang, dan IR-64. Varietas padi yang banyak digunakan oleh petani padi ladang di daerah penelitian, yaitu IR-64. Penggunaan benih padi ladang rata-rata per hektar di Kecamatan Sidomulyo adalah $16,59 \mathrm{~kg}$. Penggunaan benih tersebut belum sesuai dengan anjuran dikarenakan keterbatasan modal yang dimiliki petani.

Penggunaan pupuk bertujuan untuk memacu pertumbuhan tanaman sekaligus meningkatkan produksi tanaman. Rata-rata penggunaan pupuk petani padi ladang belum sesuai dengan anjuran. Hal ini disebabkan petani kurang mendapatkan informasi dari penyuluh pertanian. Penggunaan pupuk yang kurang dari dosis anjuran akan mengakibatkan pertumbuhan tanaman menjadi terganggu dan produksi yang dihasilkan kurang maksimal. Rata-rata penggunaan benih dan pupuk petani padi ladang disajikan pada Tabel 1 .

Penggunaan tenaga kerja dalam usahatani padi ladang berasal dari dalam keluarga dan luar keluarga. Tenaga kerja yang digunakan terdiri atas tenaga kerja pria dan wanita yang dihitung dalam hari orang kerja (HOK) berdasarkan tingkat upah yang berlaku. Kegiatan usahatani padi ladang menggunakan tenaga kerja dalam meliputi, pengolahan tanah, penanaman, pemeliharaan, pengangkutan dan penjemuran. Usahatani padi ladang pada kegiatan pengolahan lahan dilakukan tanpa olah tanah. Hal tersebut dikarenakan kegiatan budidaya di lahan kering. Jumlah tenaga kerja dalam keluarga lebih banyak dibandingkan tenaga kerja luar keluarga yaitu sebesar 15,50 HOK tenaga kerja luar keluarga dan 30,19 HOK tenaga kerja dalam keluarga. Total tenaga kerja usahatani padi ladang adalah 45,69 HOK.

Tabel 1. Rata-rata penggunaan benih dan pupuk per hektar responden petani padi ladang

\begin{tabular}{lrr}
\hline Jenis & Per hektar & \multicolumn{2}{c}{ Anjuran } \\
\hline Benih & 16,59 & $\pm 30 \mathrm{~kg}$ \\
Pupuk kandang & 179,39 & 200 \\
Pupuk Urea & 176,44 & 200 \\
Pupuk TSP & 74,51 & 75 \\
Pupuk KCl & 19,20 & 50 \\
\hline Sumber : BPTP Jawa Tengah (2007) &
\end{tabular}


Tabel 2. Analisis pendapatan usahatani padi ladang per hektar di Kecamatan Sidomulyo Kabupaten Lampung Selatan tahun 2015

\begin{tabular}{|c|c|c|c|c|}
\hline Uraian & Sat & $\mathrm{Jml}$ & $\begin{array}{c}\text { Harga } \\
\text { (Rp)/sat }\end{array}$ & Nilai(Rp) \\
\hline $\begin{array}{l}\text { Penerimaan } \\
\text { Produksi } \\
\text { Biaya Produksi } \\
\end{array}$ & $\mathrm{Kg}$ & 2.287 & 3.346 & 7.651 .528 \\
\hline \multicolumn{5}{|l|}{ I. Biaya Tunai } \\
\hline Benih & $\mathrm{Kg}$ & 16,59 & 12.600 & 209.011 \\
\hline Pupuk Kandang & $\mathrm{Kg}$ & 182,52 & 443 & 80.781 \\
\hline Pupuk Urea & $\mathrm{Kg}$ & 180,79 & 2.181 & 394.392 \\
\hline Pupuk TSP & $\mathrm{Kg}$ & 74,51 & 3.652 & 162.550 \\
\hline Pupuk KCl & $\mathrm{Kg}$ & 16,27 & 8.800 & 143.186 \\
\hline Biaya Pestisida & $\mathrm{Rp}$ & & & 452.385 \\
\hline TKLK & HOK & 26.27 & 45.000 & 1.182 .027 \\
\hline Pajak & $\mathrm{Rp}$ & & & 76.271 \\
\hline Biaya S.Lahan & $\mathrm{Ha}$ & 0.997 & 864.706 & 862.120 \\
\hline Total B.Tunai & $\mathrm{Rp}$ & & & 3.562 .723 \\
\hline \multicolumn{5}{|c|}{ II. Biaya. Diperhitungkan } \\
\hline TKDK & $\mathrm{HOK}$ & 51.17 & 45.000 & 2.302 .436 \\
\hline Sewa Lahan & $\mathrm{Ha}$ & 0.008 & 864.706 & 7.328 \\
\hline Penyusutan alat & $\mathrm{Rp}$ & & & 397.626 \\
\hline \multicolumn{5}{|l|}{ Total Biaya } \\
\hline \multicolumn{4}{|c|}{ Diperhitungkan (Rp) } & 2.707 .390 \\
\hline II. Total Biaya & $\mathrm{Rp}$ & & & 6.270 .114 \\
\hline $\begin{array}{l}\text { Pendapatan } \\
\text { Biaya Tunai }\end{array}$ & $\mathrm{Rp}$ & & & 4.088 .805 \\
\hline $\begin{array}{l}\text { Pendapatan } \\
\text { Biaya Total }\end{array}$ & $\mathrm{Rp}$ & & & 1.381 .414 \\
\hline $\begin{array}{l}\text { R/C Biaya } \\
\text { Tunai }\end{array}$ & $\mathrm{Rp}$ & & & 2,15 \\
\hline R/C Biaya Total & $\mathrm{Rp}$ & & & 1,22 \\
\hline
\end{tabular}

\section{Analisis Pendapatan Usahatani Padi Ladang}

Pendapatan merupakan ukuran keberhsilan dalam usahatani. Semakin besar pendapatan yang diperoleh maka usahatani tersebut semakin menguntungkan. Kecamatan Sidomulyo, khususnya Desa Bandar Dalam dan Desa Campang Tiga merupakan sebagian desa di Kecamatan Sidomulyo yang wilayahnya sebagian besar menjadi lahan padi ladang. Hasil analisis penerimaan dan pendapatan usahatani padi ladang per hektar disajikan pada Tabel 2. Rata-rata produksi padi ladang yang dihasilkan oleh petani adalah $2.287 \mathrm{~kg}$ dengan harga rata-rata $\mathrm{Rp}$ $3.346 / \mathrm{kg}$, sehingga diperoleh penerimaan usahatani padi ladang adalah $\mathrm{Rp}$ 7.651.528. Penerimaan usahatani oleh responden petani padi ladang masih dapat ditingkatkan lagi. Hal ini erat hubungannya dengan produksi padi dan harga jual yang petani responden terima. Produksi padi dapat ditingkatkan dengan cara menggunakan input sesuai dosis anjuran sehingga produksi padi ladang dapat meningkat.
Biaya yang dikeluarkan dalam usahatani padi dapat dibagi menjadi dua, yaitu biaya tunai dan biaya diperhitungkan. Biaya tunai adalah biaya yang dikeluarkan petani responden secara tunai dalam usahatani padi, terdiri dari biaya benih, pupuk, pestisida, tenaga kerja luar keluarga, pajak, dan sewa lahan. Biaya tenaga kerja yang dikeluarkan petani secara tunai terdiri dari biaya upah persiapan lahan, penanaman, pemupukan, pemeliharaan, panen, pengangkutan, dan penjemuran. Biaya diperhitungkan adalah biaya yang tidak dikeluarkan dalam usahatani padi akan tetapi dihitung sebagai biaya, terdiri dari biaya penyusutan alat, tenaga kerja dalam keluarga, dan sewa lahan (lahan milik sendiri tetapi dihitung sebagai sewa). Komponen biaya terbesar yang dibayarkan oleh petani padi ladang adalah untuk membayar sewa lahan dan tenaga kerja. Sebagian besar petani di Kecamatan Sidomulyo kepemilikan lahan dengan status sewa.

Nilai $\mathrm{R} / \mathrm{C}$ rasio usahatani padi ladang atas biaya tunai adalah 2,15 berarti bahwa setiap biaya tunai yang dikeluarkan $\mathrm{Rp} 1,00$ akan menghasilkan penerimaan sebesar $\mathrm{Rp} 2,15$, sedangkan $\mathrm{R} / \mathrm{C}$ rasio atas biaya total adalah 1,22 berarti bahwa setiap biaya total yang dikeluarkan $\mathrm{Rp} \quad 1,00$ akan menghasilkan penerimaan sebesar $\mathrm{Rp}$ 1,22. Kondisi ini berbeda dengan penelitian Purba (2005) tentang analisis pendapatan dan faktorfaktor yang mempengaruhi produksi cabang usahatani padi ladang di Kabupaten Karawang, menghasilkan R/C biaya total 0,76 , artinya $\mathrm{R} / \mathrm{C}<1$ maka dapat disimpulkan bahwa usahatani padi ladang di daerah penelitian tidak menguntungkan bagi petani. Hasil tersebut lebih rendah dibandingkan penelitian ini karena berbagai faktor yang berbeda, yaitu iklim, kondisi tanah, penggunaan input, dan lain-lain.

\section{Analisis Fungsi Produksi Stochastic Frountier}

Pembahasan mengenai efisiensi teknis dan faktorfaktor yang mempengaruhinya diuraikan berdasarkan hasil yang diperoleh dari analisis fungsi produksi stochastic frountier. Koefisien regresi fungsi produksi frountier dengan pendugaan fungsi produksi stochastic frountier, dengan menggunakan software frountier 4.1. Hasil pendugaan fungsi produksi menunjukkan nilai $l o g$ likelihood dengan metode MLE adalah 1,04 (Tabel 3). Nilai tersebut lebih besar dari nilai $\log$ likelihood metode OLS $(-7,80)$ yang berarti fungsi produksi metode MLE ini adalah baik dan sesuai dengan kondisi di lapang. 
Tabel 3. Hasil pendugaan fungsi produksi produksi stochastic frountier padi ladang dengan menggunakan metode MLE

\begin{tabular}{|c|c|c|c|}
\hline Variabel & Koef.Regresi & Standar eror & t-ratio \\
\hline - Intercep & $-0,5303+00$ & $0,1081+00$ & $-0,4903+01$ \\
\hline - Lahan & $0,8633-15 * * *$ & $0,8060-16$ & $0,1071+02$ \\
\hline - Benih & $0,1154-13 *$ & $0,8971-14$ & $0,1287+01$ \\
\hline $\begin{array}{l}\text { - Pupuk } \\
\text { TSP }\end{array}$ & $0,1075-13 * * *$ & $0,2080-14$ & $0,5169+01$ \\
\hline $\begin{array}{l}\text { - Tenaga } \\
\text { kerja }\end{array}$ & $-0,1146-13$ & $0,2650-13$ & $0,4324+00$ \\
\hline $\begin{array}{l}\text { - Sigma } \\
\text { squared }\end{array}$ & $0,1166+00 * *$ & $0,5406-01$ & $0,2158+01$ \\
\hline - Gamma & $0,9238+00 * * *$ & $0,9960-01$ & $0,9275+01$ \\
\hline \multicolumn{2}{|c|}{ Log-likelihood OLS } & $-0,7804+01$ & \\
\hline \multicolumn{2}{|c|}{ Log-likelihood MLE } & $0,1049+01$ & \\
\hline \multicolumn{2}{|l|}{$\mathrm{LR}$} & $0,1770+02$ & \\
\hline Keterangan : **: & $\begin{array}{l}=99 \text { persen }(\mathrm{t} \mathrm{ta} \\
=95 \text { persen }(\mathrm{t} \mathrm{tab} \\
=80 \text { persen }(\mathrm{t} \mathrm{tab}\end{array}$ & $\begin{array}{l}=2,4048) \\
=1,6765) \\
=1,2800)\end{array}$ & \\
\hline
\end{tabular}

Nilai sigma-square $(\sigma)$ dan gamma $(\gamma)$ yang diperoleh dari pendugaan dengan metode MLE adalah sebesar 0,1166 dan 0,9238 dan signifikan pada tingkat kesalahan 1 persen. Nilai $(\sigma)$ yang lebih besar dari nol menunjukkan bahwa terdapat pengaruh dari technical inefficiency dalam model. Hal ini sesuai dengan literatur yang menyebutkan bahwa apabila nilai $\sigma=0$ maka tidak terdapat pengaruh dari technical inefficiency. nilai $(\gamma)$ menunjukkan bahwa variasi nilai komposit eror (kesalahan) disebabkan oleh komponen technical inefficiency. Hasil penelitian, nilai $(\gamma)$ 0,9238 menunjukkan bahwa variasi nilai komposit eror (kesalahan) disebabkan oleh komponen technical inefficiency yang tinggi yaitu sebesar 0,9238 (Coelli dan Battese 1998). Hal ini menujukkan bahwa adanya perbedaan antara produksi sebenarnya dengan produksi maksimum lebih disebabkan oleh efek inefisiensi teknis, bukan oleh faktor eror yang merupakan faktor lain yang tidak terdapat di dalam model.

Hasil pendugaan fungsi produksi stochastic frountier padi ladang dengan menggunakan metode MLE. Rata-rata usahatani padi ladang memiliki koefisien regresi yang berpengaruh nyata pada tingkat kepercayaan 99 persen yaitu luas lahan $\left(\mathrm{X}_{1}\right)$, dan pupuk TSP $\left(\mathrm{X}_{3}\right)$, variabel benih $\left(\mathrm{X}_{2}\right)$ berpengaruh nyata pada tingkat kepercayaan 80 persen, sedangkan tenaga kerja $\left(\mathrm{X}_{4}\right)$ tidak berpengaruh nyata. Hal ini berarti bahwa dengan penambahan luas lahan, benih, dan jumlah pupuk sebesar satu persen maka akan menambah produksi sebesar nilai koefisien frontier tersebut. Variabel tenaga kerja tidak berpengaruh nyata terhadap poduksi padi ladang. Tenaga kerja tidak berpengaruh nyata karena tingkat produktivitas tenaga kerja antar usahatani responden petani padi ladang di Kecamatan Sidomulyo berbeda, dan curahan tenaga kerja tidak menjamin peningkatan produksi usahatani responden petani padi ladang.

\section{Analisis Efisiensi dan Inefisiensi Teknis}

Efisiensi teknis dianalisis dengan menggunakan model fungsi produksi stochastic frountier melalui pendekatan dari sisi output. Kategori yang digunakan dalam peneitian adalah sangat efisien jika memiliki nilai $\geq 0,90$, cukup efisien jika nilai 0,70- 0,89, dan belum efisien < 0,70 (Coelli and Battese, 1998). Dilihat dari sebaran nilai efisiensi teknis, jumlah petani responden sebanyak 26 petani memiliki nilai efisiensi $\geq 0,70$, dan jumlah petani responden sebanyak sebanyak 28 petani memiliki nilai efisiensi $\leq 0,70$. Rata-rata efisiensi teknis 0,71 , artinya secara teknis responden petani padi ladang di Kecamatan Sidomulyo cukup efisien. Hasil penelitian sejalan dengan penelitian Stephanie (2012), menganalisis efisiensi teknis dengan nilai efisiensi teknis 0,712. Terdapat perbedaan hasil penelitian Stephanie (2012), penelitian tersebut menganalisis efisiensi teknis padi ladang dengan banyak varietaspadi yang digunakan. Sebaran efisiensi teknis dari model yang digunakan disajikan pada Tabel 4.

Tingkat efisiensi teknis dapat diartikan berwajah ganda, disatu sisi tingkat efisiensi teknis yang tinggi mencerminkan prestasi petani dalam keterampilan manajerial usahatani padi ladang adalah cukup tinggi dan efisien dalam pengalokasian penggunaan input. Sisi lain, tingkat efisiensi tinggi merefleksikan bahwa peluang yang kecil untuk meningkatkan produktivitas yang cukup tinggi, karena senjang antara produktivitas yang telah dicapai dengan produktivitas maksimum yang dapat dicapai dengan sistem pengelolahan terbaik cukup sempit. (Noor 1996).

Tabel 4. Sebaran responden berdasarkan tingkat efisiensi teknis usahatani padi ladang di Kecamatan Sidomulyo Kabupaten Lampung Selatan

\begin{tabular}{|c|c|c|}
\hline Tingkat & \multicolumn{2}{|c|}{ Indeks efisiensi } \\
\hline Efisiensi teknis & Jumlah & Persentase \\
\hline$<0,7$ & 28 & 52 \\
\hline$\geq 0,7$ & 26 & 48 \\
\hline Total & 54 & 100 \\
\hline Rata-rata & 0,7146 & \\
\hline Minimum & 0,3693 & \\
\hline Maksimum & 0,9694 & \\
\hline
\end{tabular}


Tabel 5. Hasil pendugaan faktor-faktor yang mempengaruhi inefisiensi teknis padi ladang di Kecamatan Sidomulyo Kabupaten Lampung Selatan.

\begin{tabular}{llll}
\hline \multicolumn{1}{c}{ Variabel } & \multicolumn{1}{c}{ Koeff reg. } & $\begin{array}{c}\text { Standar } \\
\text { Eror }\end{array}$ & t-ratio \\
\hline - Intercep & $0,3042+00$ & $0,3281+00$ & $0,9270+00$ \\
- Umur petani & $-0,3718-14^{*}$ & $0,2507-14$ & $0,1483+01$ \\
- Tingkat & $-0,3307-13^{*}$ & $0,2332-13$ & $-0,1418+01$ \\
$\quad \begin{array}{l}\text { pendidikan } \\
\text { - Pengalaman }\end{array}$ & $-0,4548-14 *$ & $0,2775-14$ & $-0,1638+01$ \\
$\quad$ usahatani & & & \\
- Sumber & $-0,3380-13 *$ & $0,2233-13$ & $-0,1513+01$ \\
$\quad$ modal & & & \\
\hline Keterangan :*** & $=99$ persen $(\mathrm{t}$ tabel $=2,4048)$ & \\
$* *$ & $=95$ persen $(\mathrm{t}$ tabel $=1,6765)$ & \\
$*$ & $=80$ persen $(\mathrm{t} \mathrm{tabel}=1,2800)$. &
\end{tabular}

Sumber-sumber Inefisiensi Teknis

Sumber-sumber inefisiensi teknis diperoleh dari hasil penggunaan model produksi stochastic frontier. Hasil pendugaan model efek inefisiensi tenis dijelaskan pada Tabel 5. Variabel faktorfaktor berpengaruh nyata dalam menjelaskan inefissiensi teknis di dalam proses produksi responden petani padi ladang. Hasil pendugaan tersebut menunjukkan bahwa umur petani, tingkat pendidikan, pengalaman berusahatani dan sumber modal berpengaruh nyata terhadap inefisiensi teknis petani responden pada taraf kepercayaan 80 persen. Variabel umur menunjukkan bahwa semakin tua umur petani akan menurunkan tingkat inefisiensi teknis, atau dengan kata lain semakin tua umur petani semakin efisien usahatani yang dikelola. Menurut Widodo (1989), petani berusia lanjut semakin lemah dalam berusahatani namun petani yang lebih tua biasanya semakin berani dalam mengambil resiko.

Variabel pendidikan menunjukkan bahwa semakin tinggi tingkat pendidikan formal yang ditempuh petani, maka akan menurunkan tingkat inefisiensinya atau dengan kata lain usahatani padi semakin efisien. Variabel pengalaman usahatani menunjukkan bahwa semakin lama pengalaman petani berusahatani padi ladang, maka semakin efisien dalam mengelola usahataninya, karena semakin lama berusahatani petani semakin memiliki pengetahuan dalam mengelola berusahatani padi ladang dengan baik. Sumber modal dimasukkan dalam model efek efisiensi teknis dengan dugaan dapat menurunkan inefisiensi teknis petani padi ladang di daerah penelitian. Faktor ketersediaan modal usaha untuk membiayai usahatani menjadi masalah utama petani responden. Petani responden di Kecamatan
Sidomulyo mayoritas petani mengusahakan usahatani dengan sumber modal meminjam, sumber peminjaman modal tersebut adalah pedagang pengepul.

\section{Analisis Efisiensi Alokatif dan Ekonomi}

Pembahasan mengenai efisiensi alokatif dan ekonomi dari analisis fungsi biaya produksi stochastic frountier, dengan menggunakan software frountier 4.1. Hasil pendugaan fungsi biaya produksi stochastic frountier disajikan pada Tabel 6. Model fungsi produksi padi ladang menunjukkan, nilai log likelihood dengan metode MLE $(-27,1614)$ adalah lebih besar dari nilai $\log$ likelihood dengan metode OLS $(-35,2980)$ yang berarti fungsi produksi dengan metode MLE ini adalah baik dan sesuai dengan kondisi di lapang. Fungsi biaya stochastic frountier padi ladang memiliki koefisien regresi yang berpengaruh nyata pada tingkat kepercayaan 99 persen yaitu biaya lahan $\left(\mathrm{P}_{1}\right)$, biaya benih $\left(\mathrm{P}_{2}\right)$, biaya pupuk $\left(\mathrm{P}_{3}\right)$, dan biaya tenaga kerja $\left(\mathrm{P}_{4}\right)$. Penggunaan input produksi yang efisien akan menghasilkan produksi yang maksimum. Hasil penelitian di Kecamatan Sidomulyo petani padi ladang kurang mampu mengalokasikan input dengan harga input dan produk marjinal yang dihasilkan.

Tabel 6. Hasil pendugaan fungsi biaya produksi stochastic frountier padi ladang dengan menggunakan metode MLE di Kecamatan Sidomulyo Kabupaten Lampung Selatan.

\begin{tabular}{|c|c|c|c|}
\hline Variabel & Koef.Regresi & Standar eror & t-ratio \\
\hline - Intercep & $-0,1752+01$ & $0,2607+01$ & $-0,6719+00$ \\
\hline $\begin{array}{l}\text { - Biaya luas } \\
\text { lahan }\end{array}$ & $-0,1212-12$ & $0,8694-14$ & $-0,1394+02$ \\
\hline - Biaya benih & $0,1144+018^{\text {***** }}$ & $0,2430+00$ & $0,4710+01$ \\
\hline 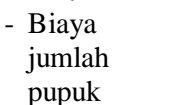 & $0,8609-13^{\text {*** }}$ & 0,9066-14 & $0,9495+01$ \\
\hline $\begin{array}{l}\text { - Biaya } \\
\text { tenaga kerja }\end{array}$ & $0,9168-01^{* * *}$ & $0,3269-01$ & $0,2803+01$ \\
\hline - Sigma & $0,3925+00^{* * * *}$ & $0,6125-01$ & $0,6407+01$ \\
\hline - Gamma & $0,9999+00^{* * * *}$ & 0,2839-03 & $0,3521+04$ \\
\hline \multicolumn{2}{|c|}{ Log-likelihood OLS } & $-0,3529+02$ & \\
\hline \multicolumn{2}{|c|}{ Log-likelihood MLE } & $-0,2716+02$ & \\
\hline \multicolumn{2}{|l|}{ LR } & $0,1627+02$ & \\
\hline Keterangan : **: & \multicolumn{3}{|c|}{$\begin{array}{l}=99 \text { persen }(\mathrm{t} \text { tabel }=2,4048) \\
=95 \text { persen }(\mathrm{t} \text { tabel }=1,6765) \\
=80 \text { persen }(\mathrm{t} \text { tabel }=1,2800)\end{array}$} \\
\hline
\end{tabular}


Tabel 7. Sebaran responden berdasarkan tingkat efisiensi alokatif dan ekonomi usahatani padi ladang di Kecamatan Sidomulyo Kabupaten Lampung Selatan.

\begin{tabular}{lcccc}
\hline Tingkat & \multicolumn{2}{c}{ Efisiensi alokatif } & \multicolumn{2}{c}{ Efisiensi ekonomi } \\
\cline { 2 - 5 } Efisiensi & Jumlah & Persentase & Jumlah & Persentase \\
\hline$<0,7$ & 24 & 44 & 34 & 62 \\
$\geq 0,7$ & 30 & 56 & 30 & 38 \\
\hline Total & 54 & 100 & 54 & 100 \\
\hline Rata-rata & 0,8144 & & 0,5819 & \\
\hline Min & 0,1752 & & 0,1661 & \\
\hline Mak & 1,9299 & & 0,9998 & \\
\hline
\end{tabular}

\section{Sebaran Efisiensi Alokatif dan Ekonomi}

Analisis efisiensi alokatif dan ekonomi dianalisis dari harga input yang berlaku pada tingkat petani. Nilai efisiensi ekonomi (EE) per individu usahatani diperoleh dari satu dibagi nilai efisiensi biaya, dan efisiensi alokatif (AE) per individu usahatani diperoleh dari efisiensi teknis dan ekonomis. Efisiensi ekonomi merupakan efek gabungan dari efisiensi teknis dan efisiensi alokatif sehingga usahatani dapat efisien secara ekonomis jika efisiensi teknis dan efisiensi alokatif telah tercapai. Nilai efisiensi ekonomi (EE) per individu usahatani diperoleh dari satu dibagi nilai efisien biaya, dan efisiensi alokatif (AE) per individu usahatani diperoleh dari efisiensi teknis dan ekonomis.

Tingkat efisiensi alokatif dan ekonomi petani responden disajikan pada Tabel 7. Hasil sebaran nilai efisiensi alokatif ditemukan petani responden sebanyak 28 petani memiliki nilai efisiensi $\leq 0,70$, dan petani responden sebanyak 26 petani memiliki nilai efisiensi $\geq 0,70$. Sebaran efisiensi ekonomi ditemukan petani responden sebanyak 33 petani memiliki nilai efisiensi $\leq 0,70$, dan petani responden sebanyak 21 petani memiliki nilai efisiensi $\geq 0,70$. Rata-rata efisiensi alokatif dan efisiensi ekonomi sebesar 0,8144 dan 0,5819. Hal ini menunjukkan petani sudah mencapai efisiensi alokatif dan belum mencapai efisiensi ekonomi.

Tabel 8. Sebaran responden berdasarkan tingkat efisiensi usahatani padi ladang di Kecamatan Sidomulyo Kabupaten Lampung Selatan

\begin{tabular}{lcr}
\hline Tingkat & \multicolumn{2}{c}{ Jumlah responden } \\
\cline { 2 - 3 } Efisiensi & Jumlah & Persentase \\
\hline Sangat Efisien & 0 & 0 \\
Cukup Efisien & 6 & 11 \\
Belum Efisien & 48 & 89 \\
\hline Total & 54 & 100 \\
\hline
\end{tabular}

Penggunaan input yang berlebih akan mengakibatkan inefisiensi biaya. Petani memiliki efisiensi alokatif yang maksimum sebesar 1,9299 dan minimumnya sebesar 0,1752 . Petani memiliki nilai efisiensi ekonomi maksimum sebesar 0,9998 dan nilai minimum sebesar 0,1661 . Rata-rata nilai efisiensi alokatif dan ekonomi rendah disebabkan pengalokasian input tidak optimal dan informasi harga input di daerah penelitian tidak sempurna.

Mengacu pada (Coelli and Battese, 1998) bahwa suatu usahatani dikatakan sangat efisien jika TE, $\mathrm{EE}$ dan $\mathrm{AE} \geq 0,90$, cukup efisien jika $0,70 \leq \mathrm{TE}$ dan $\mathrm{EE}$ dan $\mathrm{AE}<0,90$, dan belum efisien jika TE, $\mathrm{EE}$ dan $\mathrm{AE}<0,70$. Distribusi tingkat efisiensi usahatani padi ladang secara rinci disajikan pada Tabel 8. Tingkat efisiensi usahatani responden petani padi ladang didaerah penelitian petani sebesar 0 persen sangat efisien, 11 persen cukup efisien, dan 89 persen belum efisien secara teknis. Petani responden belum efisien secara teknis dikarenakan penggunaan input belum tepat dan belum sesuai anjuran budidaya, dan petani belum efisien secara alokatif dikarenakan belum mampu mencari informasi harga input agar petani mampu mengalokasikan biaya terhadap modal. Efisiensi ekonomi merupakan efek gabungan dari efisiensi teknis dan efisiensi alokatif sehingga usahatani dapat efisien secara ekonomis jika efisiensi teknis dan efisiensi alokatif telah tercapai.

\section{KESIMPULAN}

Tingkat pendapatan usahatani padi ladang pada musim hujan November 2015 - Maret 2016 sebesar Rp 1.381.414,00/ha dan usahatani padi ladang menguntungkan dengan nilai $\mathrm{R} / \mathrm{C}$ atas biaya total sebesar 1,22. Tingkat efisiensi produksi usahatani petani padi ladang sebesar 89 persen belum efisien.

\section{DAFTAR PUSTAKA}

BPS [Badan Pusat Statistik]. 2016. Luas Panen, Produksi, dan Produktivitas Padi Menurut Kabupaten/Kota di Provinsi Lampung 2015. http://lampung.bps.go.id/linkTaBelStatis/view /id/447. [29 Agustus 2016].

BPS [Badan Pusat Statistik]. 2016. Luas Panen, Produksi, dan Produktivitas Padi Menurut Kecamatan di Kabupaten Lampung Selatan, 2015. https://lampungselatankab.bps.go.id /backend/pdf_publikasi/Kabupaten-LampungSelatan-dalam-Angka-2016.pdf. [29 Agustus 2016]. 


\section{JIIA, VOLUME 6, No. 1, FEBRUARI 2018}

BPTP NAD [Balai Pengkajian Teknologi Pertanian Nanggro Aceh Darusalam]. 2009. Budidaya Tanaman Padi. http://nad.litbang .pertanian.go.id/ind/images/dokumen/modul/1 0-Budidaya-padi.pdf. [6 Oktober 2016].

BPTP [Balai Pengkajian Teknologi Pertanian] Jawa Tengah. 2007. Teknologi Budidaya Padi Gogo. ttp://jateng.litbang.pertanian.go.id. [5 Januari 2017].

Coelli T and Battese G E. 1998. An introduction to efficiency andproductivity analysis. Kluwer Academic Publishers. Boston.

Kementrian Pertanian. 2015. Outlook Padi. http://www.pertanian.go.id/ap_pages/mod /datatp. [29 September 2016].

Mantra ID. 2008. Demografi Umum. Pustaka Pelajar. Yogyakarta.

Noor M. 1996. Padi Lahan Marginal. Penebar Swadaya. Bogor.

Permandi dan Toha H.1996. Peningkatan Produktivitas Padi Gogo Dengan Penanaman Kultivar Unggul Dan Pemupukan Nitrogen. Universitas Indonesia. Jakarta.
Purba M. 2005. Analisis pendapatan dan faktorfaktor yang mempengaruhi produksi cabang usahatani padi ladang di Kabupaten Karawang. Jurnal Ilmu Ilmu Pertanian, 25 (1) : 119-125. http://jurnal.fp.uns .ac.id/index.php /caraka/article/view/167/134 [23 Oktober 2016].

Soekartawi. 1995. Analisis Usahatani. UIPRESS. Jakarta.

Soekartawi. 1984. Ilmu Usahatani dan Penelitian Untuk Pengembangan Petani Kecil. Universitas Indonesia. Jakarta.

Stephanie H. 2012. Analisis Efisiensi Teknis Dan Pendapatan Usahatani Padi Sawah Kabupaten Indramayu. http://repository.ipb.a c.iditstream/handle/123456789/58132/BABpe rsen20VIpersen20Analisispersen20Efisiensipe rsen20Teknis.pdf?sequence=7\&isAllowed $=\mathrm{y}$. [23 Oktober 201].

Widodo S. 1989. Producion Efficiency of Rice Farmers in Java-Indonesia. Gajah Mada University Press. Yogyakarta. 